\title{
Anti-GCC Antibody-Drug Conjugate MLN0264
}

National Cancer Institute

\section{Source}

National Cancer Institute. Anti-GCC Antibody-Drug Conjugate MLN0264. NCI Thesaurus. Code C101524.

An antibody-drug conjug ate (ADC) containing a monoclonal antibody directed against guanylyl cyclase C (GCC or GUCY2C) conjug ated to monomethylauristatin E (MMAE), an auristatin derivative and a potent microtubule inhibitor, with potential antineoplastic activity. The monoclonal antibody moiety of MLN0264 selectively binds to GCC, a transmembrane receptor normally found on intestinal cells and dopamine neurons in the brain, but is also overexpressed on the surface of gastrointestinal cancers. Upon internalization and proteolytic cleavage, MMAE binds to tubulin and inhibits its polymerization, resulting in G2/M phase arrest and tumor cell apoptosis in GCCexpressing tumor cells. 